\title{
Kinetics and Reactor Model of Biogas Production from Abattoir Waste (Cow Dung)
}

\author{
Akpa Jackson Gunorubon ${ }^{1}$, Igbagara Princewill Woyinbrakemi ${ }^{2}$, Adeloye Olalekan Michael ${ }^{1, *}$ \\ ${ }^{1}$ Department of Chemical, Petrochemical Engineering Rivers State University, Port-Harcourt, Nigeria \\ ${ }^{2}$ Department of Chemical Engineering, Federal University of Petroleum Resources, Effurun, Nigeria
}

Email address:

adeloye.olalekan@yahoo.com (A. O. Michael)

${ }^{*}$ Corresponding author

\section{To cite this article:}

Akpa Jackson Gunorubon, Igbagara Princewill Woyinbrakemi, Adeloye Olalekan Michael. Kinetics and Reactor Model of Biogas Production from Abattoir Waste (Cow Dung). Chemical and Biomolecular Engineering. Vol. 6, No. 3, 2021, pp. 49-58. doi: 10.11648/j.cbe.20210603.12

Received: August 3, 2021; Accepted: August 16, 2021; Published: September 6, 2021

\begin{abstract}
A laboratory scale anaerobic digester unit was setup and applied for biogas production from cow dung. Anaerobic digestion was conducted at $35^{\circ} \mathrm{C}$ and observed for a retention period of fifty days. The ambient and slurry temperatures, $\mathrm{pH}$ of slurry and amount of biogas produced were measured on a four-day interval basis. The experimental data obtained were used for kinetic studies by fitting the data to known kinetic models such as Linear, Exponential, Gaussian, Logistics and Modified Gompertz. The constants in these models were determined by linear regression using the Matlab curve fitting tool box. A reactor model for the bioreactor was also developed. The experimental results showed biogas production occurred within the mesophilic temperature range $\left(28^{\circ} \mathrm{C}-29^{\circ} \mathrm{C}-36^{\circ} \mathrm{C}\right)$, measured $\mathrm{pH}$ values were $6.9-7-6.1$ for fifty days' production (retention) period. The volume of biogas produced was $27.7 \mathrm{ml} / \mathrm{g}$, maximum production rate of biogas is $5.1 \mathrm{ml} / \mathrm{g} / \mathrm{day}$ and the minimum time required for biogas production (the lag phase) was three days. The kinetic evaluation of the production data showed that the coefficient of determination $\left(\mathrm{R}^{2}\right)$ were as follows, linear model: 0.9673 and 0.7808 , exponential model: 0.9742 and 0.779 for the ascending and descending climbs respectively, Gaussian model: 0.9132, Logistic Growth model: 0.9979 and Modified Gompertz model: 0.999 with the logistic model gave the kinetic constant of 2.564. Thus, the Modified Gompertz model yielded high accuracy result. In addition, the reactor model developed solved with the Modified Gompertz kinetic model predicted the biogas production process accurately with cumulative biogas production of $28.13 \mathrm{ml} / \mathrm{g}$ compared to the experimental cumulative production of $27.7 \mathrm{ml} / \mathrm{g}$ with a deviation of $1.53 \%$.
\end{abstract}

Keywords: Anaerobic Digester, Cow Dung, Biogas, Cumulative Biogas, Kinetic Models

\section{Introduction}

The most important factors of civilized community are the availability of energy for domestic, agricultural and industrial purpose [1], which is a tool of economic growth. Energy consumption reflects a nation's level of development. The sources of renewable energy includes sunlight, wind, rain tides and geothermal heat that may be replenished naturally. The technologies of renewable energy are solar power, wind power, hydroelectricity, micro-hydro, biomass and biofuels for transportation. In 2006, energy consumption from renewable sources was about $18 \%$, biomass yielded $13 \%$ and hydropower provided $30 \%$ as another source of renewable energy [2]. Biogas production from renewable resources is now a prominent feature of most developed and developing countries of the world. Despite the differences in international point of view about the technology, there is acceptance about its role in the domestic and agricultural life of the rural citizenries in countries like India, china, Korea and Malaysia. It is used for cooking, crop drying and soil fertilizing [3]. Biogas is evolved when biological materials are degraded y bacterial in the absence of oxygen (anaerobic digestion) [4].

Anaerobic treatment refers to the application of biological processes for breaking organic matter without the use of oxygen and the stabilization of these materials by conversion of methane and carbon dioxide and a nearly stable residue. Animal wastes can be used as a fuel energy source; they 
possess high level of organic matter that could be converted into energy - a supplement for fossils. Animal waste are abundant all over the world with Nigeria producing about 227,500 tons of fresh waste each day [5]. A kilogram of fresh animal waste has been reported to produce about $0.003 \mathrm{~m}^{3}$ of gas per day. This shows theoretically that Nigeria can or has the potential to produce 6.8 million $\mathrm{M}^{3}$ of biogas daily, which in terms of energy is equivalent to about 3.9 million liters of petroleum [6]. The application of biogas can provide special impetus in both rural and urban area. Locally accessible materials available in developing world can be used to build biogas plant. The anaerobic digestion of municipal waste can be of value as it combines waste removal and stabilization with net fuel (Biogas) production, and the residue (solid or liquid) can further be used as feed or as biomass briquette [7]. Besides, the evaluation of the effect of cattle manure collected at different time inoculated with rumen fluid of cattle on biogas production at mesophilic condition was performed. The results showed the mixture $\mathrm{pH}$ before and after the biogas evolution as 7.34 and 7.15 respectively with a distinct difference $(\mathrm{P}<0.05)$ in the cattle manure taken at zero and 24 hours between the treatment group and control. The best observed yield of biogas was seen in the lumen fluid range of $25-50 \%$ Also, high yield of biogas was produced from cattle manure taken after 12 hours of defecation as compared to 0 hour and 24 hours of cattle post-defecation [8]. In addition, anaerobic digestion study of kitchen waste to produce biogas by treating food effluent using microorganisms was carried out. The mixture of vegetable wastes with inoculum of previous cow dung slurry was digested anaerobically. These mixtures were applied for biogas production at $37^{\circ} \mathrm{C}$ in laboratory reactor. They reported that the yield of biogas was with a considerable decline rate in the values of COD, BOD, $\mathrm{pH}$, acidity and alkalinity and methanogen gradually converts the organic acids into the methane gas and carbon dioxide, which indicates that the waste has better anaerobic biodegradability [9]. Also, the feasibility of biogas production from slaughterhouse with anaerobic digestion process was conducted in a mini digester of 20-liter capacity, slaughterhouse waste (SHW) slurry and other with cow dung (CD) slurry. The study was performed using a batch reactor for a period of 43 days, with daily average temperature varying between $20^{\circ} \mathrm{C}$ to $28^{\circ} \mathrm{C}$. It was observed that the amount of biogas that can be produced from 23 slau ghterhouses present in Lalitpur Sub Metropolitan City is $103.2 \mathrm{~m}^{3} /$ day. The biogas yield from SHW is higher in comparison to cow dung. The specific biogas yield from SHW was $0.201 \mathrm{~m}^{3} / \mathrm{kg} \mathrm{VS}$ which were higher in comparison to cow dung, having $0.18 \mathrm{~m}^{3} / \mathrm{kg} \mathrm{VS}$ and the average methane content of SHW was $55.8 \%$, which is in par with the methane content of cow dung [10]. The large volume of waste produced by animals in farms have made animal waste treatment a concern. Adequate treatment is needed to reduce or prevent the effects of these wastes on the quality of water, quality of air and public health. Thus, the results of this research study showed that abattoir waste would serve as a substrate for biogas production and its utilization (substrate) for biogas production will avert disposal issues and create an alternative source of sustainable energy. Therefore, this research study conducted the kinetic studies of this waste to obtain kinetic parameters of biogas production from cow dung that are essential for bio-digester studies and design.

\section{Materials and Experimental Method}

Fresh cow dung (abattoir waste) was taken from the slaughter house at mile 3 Diobu, Port Harcourt and a $20 \mathrm{~L}$ bio-digester calibrated plastic container equipped with a digital $\mathrm{pH}$ and temperature probe, stirrer and sampling ports were applied in carrying out this analysis.

\subsection{Experiment}

The experimental procedures applied in performing this research study are discussed thus.

\subsubsection{Preparation of Abattoir Waste}

The cow dung was sun dried, mechanically crushed (using mortar and pestle) for homogeneity of the dung and weighed. The cow dung was analyzed (characterized) to determine the following properties such as total solid (TS), volatile solid (VS); chemical oxygen demand (COD), $\mathrm{NH}_{3}-\mathrm{N}$ (Ammonianitrogen ratio), $\mathrm{pH}$ and moisture content using procedures outlined in standard methods [11, 12]. Ammonia - nitrogen $\left(\mathrm{NH}_{3}-\mathrm{N}\right)$ content was analyzed using the spectrophotometer. In addition, the cow dung slurry was prepared by diluting with distilled or tap water in the ratio 1:2 (1 kg of cow dung to $2 \mathrm{~kg}$ of water). The fibers were removed by screening through a sieve of $0.5 \mathrm{~cm}$ by $0.5 \mathrm{~cm}$ mesh size. The slurry (substrate) was stored at $4^{\circ} \mathrm{C}$ and the ratio of mixing was evaluated by the cow dung moisture content [13].

\subsubsection{Biogas Production}

The experimental set up for production of biogas was conducted in the Kinetics Laboratory of the Department of Chemical/Petrochemical Engineering, Rivers State University, Port-Harcourt, Nigeria. The experiment was carried out at a temperature of $35^{\circ} \mathrm{C}$ by circulating water from a thermostat through a water jacket surrounding the bioreactor and mixing was aided by a mechanical stirrer set. The experimental procedure involved loading of slurry (substrate) into the bioreactor and the bioreactor properly sealed to avert air from entering the tank and carbondioxide gas was bubbled into the bio-digester to ensure anaerobic condition. The experiment was observed for a retention period of fifty days and the ambient and slurry temperatures were measured using the thermometer on a five-day interval. The $\mathrm{pH}$ of the slurry was monitored initially and on a five (5) day interval to determine the action of methanogens (which utilize the acids, carbon dioxide and hydrogen produced) using a digital $\mathrm{pH}$ meter. The quantity of gas produced was taken at 12 hours on five (5) day basis.

\subsubsection{Collection of Gas}

The gas was collected by downward displacement of water in the gas holder. The volume of displaced water was recorded as the volume of gas produced. 


\subsubsection{Methane Analysis in Biogas Produced}

The evolution of methane in the produced biogas was tested by lighting flame on a Bunsen burner connected to the digester. The gas that comes out from the digester was checked whether it burns, the colour of the flame and odour was also checked. Thus, gas chromatography was used to deduce the composition of methane in the biogas produced.

\subsection{Evaluation of Kinetic Models}

The biogas production kinetics was studied by fitting the experimental data of biogas production volume with time to evaluate kinetic expressions of biogas production. The kinetic expressions tested are discussed thus.

a) Linear Model

The linear model equation of the biogas production in the ascending and descending climbs is expressed $[14,15]$

$$
y=a+b T
$$

It assumed that biogas production rate will increase linearly with time, reach a maximum and then decrease linearly to zero with time. The constants: a ( $\mathrm{ml} / \mathrm{gm} /$ day) and $\mathrm{b}\left(\mathrm{ml} / \mathrm{gm} / \mathrm{day}^{2}\right)$ were obtained from the intercept and slope of the graph of production rate against time.

b) Exponential Model

The exponential equation for biogas production assumes that there will be exponential increase in production rate of biogas as time increases, reached maximum, and then decrease to zero exponentially with increase in time. The model as given as [16]

$$
y=a+b \exp (c T)
$$

The constants: a $(\mathrm{ml} / \mathrm{gm} /$ day $)$ and $\mathrm{b}\left(\mathrm{ml} / \mathrm{gm} /\right.$ day $\left.^{2}\right)$ were determined from the intercept and slope of the plot of biogas production rate with time.

c) Gaussian Model

The Gaussian model assumes that the biogas production rate would follow a normal distribution over the hydraulic retention time and is expressed thus.

$$
y=a \exp \left[\frac{T-T_{o}}{b}\right]^{2}
$$

d) Logistic Growth Model

The rate of production of biogas was also simulated using the logistic growth model as given by the modified Gompertz equation:

$$
Y=\frac{a}{1-b \exp (-K T)}
$$

e) Gompertz equation

The Gompertz equation expressed below was applied in simulating the biogas production rate

$$
Y=A\left\{-\exp \left[\frac{U e}{A}(\lambda-T)+1\right]\right\}
$$

\subsection{Kinetic Parameters Determination}

The kinetic parameters of the various models were evaluated after fitting the experimental data using the nonlinear curve fitting toolbox in MathLab (R2012a).

\subsection{Batch Bioreactor Model for Biogas Production}

The bioreactor used in this experiment was modelled as a constant density semi batch reactor. The principle of conservation of mass applied on the bioreactor was used to develop the model equation for predicting the cumulative volume of biogas produced daily as

$$
\frac{d V_{b g}}{d t}=-F_{o}-\left(-R_{b g}\right) M_{s l}
$$

\subsection{Determination of Reaction Rate Constant}

The various rate equations listed were fitted to the experimental results obtained and the equation with the best fit (equation with the highest regression coefficient) was chosen.

\subsection{Solution Technique}

The model equation developed was a first order ordinary differential equation. This was solved numerically using the $4^{\text {th }}$ order Runge Kutta algorithm. The algorithm was followed to develop a MathLab program using ODE45 solver.

\section{Results and Discussion}

The results obtained from the experimental analysis conducted in this research study are presented thus.

\subsection{Characterization of Cow Dung}

The results of the characterization of the biomass (cow dung) applied in this study are presented in Table 1.

Table 1. Proximate features of Fresh Cow Dung.

\begin{tabular}{lll}
\hline SN & Components & Composition (\%) \\
\hline 1 & Total Solid (g) & 6.76 \\
2 & Moisture Content (\%) & 53.4 \\
3 & $\mathrm{pH}$ & 6.70 \\
4 & Total Carbon & 36.73 \\
5 & Total Nitrogen & 1.36 \\
6 & Carbon to Nitrogen Ratio & 27.01 \\
\hline
\end{tabular}

The values of these properties were within the limits predicted by other researchers for optimum biogas production. It has been deduced that the Carbon Nitrogen ratio of feed mixtures between 25 to $30: 1$ and $8 \%$ total solid content of the slurry would yield high performance of an anaerobic digester for biogas production using dairy manure as substrate [17]. Also, the total solid content of 7.4 and $9.2 \%$ in cattle dung show the best performance for digestibility [18], while a temperature of $35^{\circ} \mathrm{C}$ and $8 \%$ total solid gave maximum gas production [19]. In addition, the $\mathrm{pH}$ value obtained in this study was in agreement with values for fresh cow dung obtained by [20,21] and are within the acceptable range of 6.65 to 7.81 for anaerobic digestion as proposed. [22] 


\subsection{Biogas (Methane) Production}

The daily and cumulative biogas production for the 50 days' study period are show in Figures 1 and 2 respectively. Production actually started on the third day (lag phase) and measured at five days' interval started slowly and increased continuously reaching a peak on the $25^{\text {th }}$ day with a $5.1 \mathrm{ml}$ yield of biogas. There was minimal increase on the tenth day, sharp increase on the fifteenth day and steady increase on the $20^{\text {th }}$ and $25^{\text {th }}$ day respectively. After the $25^{\text {th }}$ day, measured 5 days' interval production rate began to drop or decrease gradually by the $30^{\text {th }}$ day, very drastically by the $35^{\text {th }}$ to $40^{\text {th }}$ day and very gradual between $45^{\text {th }}$ to $50^{\text {th }}$ day. These results conform to typical production pattern or behavior of microbial processes with the lag, exponential growth and exponential decline phases. The dead phase will be observed if the experiment was performed for a longer period.

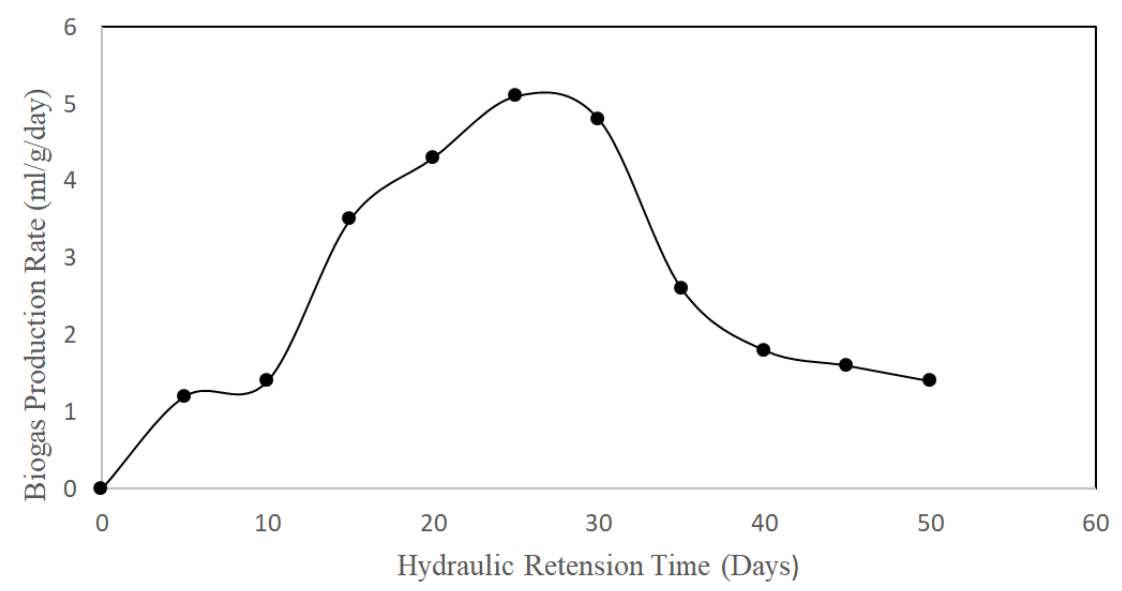

Figure 1. Biogas production Rate against Time.

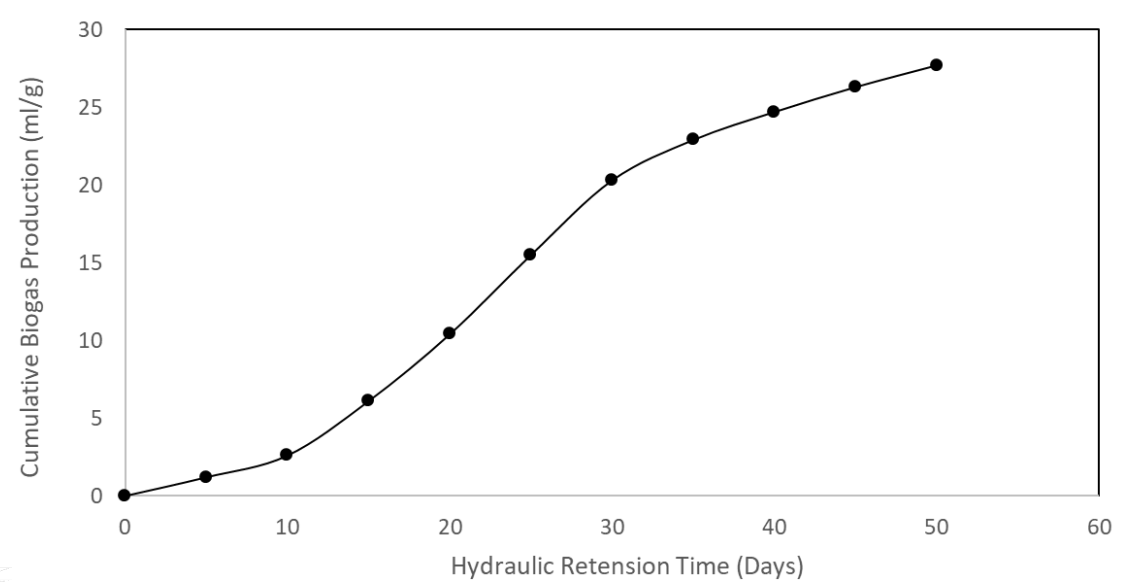

Figure 2. Cumulative Biogas Production (ml/g).

The delay in biogas production could be attributed to the lignin in feeds for cows which are mainly maize stock consisting of about $90 \%$ dry weight cellulose, hemicellulose and lignin. The lignin creates a protective barrier that hinders plant cell destruction by fungi and bacteria for conversion to biogas [24], and biogas production rate in batch condition is reported to be directly proportional to the specific growth of methanogenic bacteria [22]. The first three days indicating the lag phase of microbial growth with minimal biogas production; the $10^{\text {th }}$ to $25^{\text {th }}$ day was the exponential growth phase where biogas production increased drastically attaining a maximum of 5.1 on the $25^{\text {th }}$ day due to exponential growth of methanogens, while the $30^{\text {th }}$ to $40^{\text {th }}$ was the exponential decline phase where biogas production decreased drastically.

\subsection{Produced Gas Analysis}

The composition of the biogas produced from the experiment were within the range of typical biogas composition as reported by [23], particularly of methane, which is usually between $50-70 \%$ as shown in Table 2 .

Table 2. Analysis of Biogas Produced.

\begin{tabular}{lll}
\hline SN & Components & Compositions (\%) \\
\hline 1 & Methane & 67 \\
2 & Carbondioxide & 25 \\
3 & Hydrogen & 5 \\
4 & Nitrogen & 2 \\
5 & Other gases $\left(\mathrm{O}_{2}, \mathrm{CO}\right.$ and $\left.\mathrm{H}_{2} \mathrm{~S}\right)$ & 1 \\
\hline
\end{tabular}




\subsection{Effect of Process Variables}

The following process parameters were measured in performing this experimental analysis and their effects on the rate of biogas production are discussed thus.

\subsubsection{Effect of $P H$}

The measured $\mathrm{pH}$ in the digester during the biogas production period are shown in Figure 3.

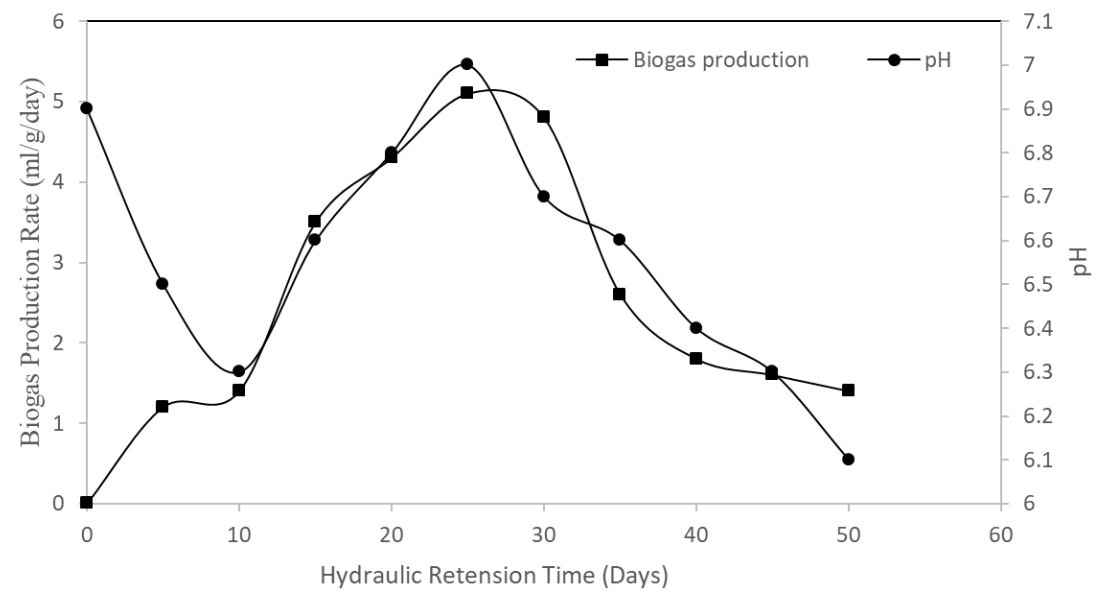

Figure 3. Changes in Biogas Production and $\mathrm{pH}$.

Figure 3 shows the changing $\mathrm{pH}$ pattern in this research study with an initial $\mathrm{pH}$ value of 6.9. The $\mathrm{pH}$ dropped throughout the first ten days to 6.3 by the tenth day, after which $\mathrm{pH}$ began to increase reaching a maximum of 7 on the $25^{\text {th }}$ day, then decreased continuously to 6.1 by the $50^{\text {th }}$ day. During the first ten days when there was a drop in $\mathrm{pH}$ from 6.9 to 6.5 to $6.3(0,5$ and 10 days), there was low biogas production of $0,1.2$ and $1.4 \mathrm{ml} / \mathrm{day}$; after the tenth day, $\mathrm{pH}$ in digester began to increase from 6.3 to 7 by the twenty fifth day. During this period of increase in $\mathrm{pH}$, daily biogas production increased continuously from $1.4 \mathrm{ml} /$ day to $3.5,4.1$ and 5.1 $\mathrm{ml} /$ day respectively at the $15^{\text {th }}, 20^{\text {th }}$ and $25^{\text {th }}$ day. After the $25^{\text {th }}$ day, pH began to decrease continuously from 7 to 6.1 on the $50^{\text {th }}$ day with the daily biogas production rate decreasing gradually by the $30^{\text {th }}$ day, drastically by the $35^{\text {th }}$ and $40^{\text {th }}$ day and then minimally from the $40^{\text {th }}$ day to the $50^{\text {th }}$ day.

Thus, $\mathrm{pH}$ is a vital factor that affects anaerobic digestion and low $\mathrm{pH}$ prevents methanogenic bacteria that are required for production of biogas $[6,19]$. PH value less than 5 or greater than 8 had also been reported to rapidly inhibits methanogenesis and anaerobic bacteria required a natural environment, hence, optimum biogas production was obtained at a $\mathrm{pH}$ range of $6.4-7.2$ [6]. The observed $\mathrm{pH}$ trends in this research is in tandem with previous studies.

\subsubsection{Effect of Temperature}

There was very minimal fluctuation in the Temperature of the digester, a drop in temperature was observed in the first ten days from 28 to $26.9^{\circ} \mathrm{C}$, then increased gradually thereafter to $29^{\circ} \mathrm{C}$ by the $25^{\text {th }}$ day and decreased again gradually to $26^{\circ} \mathrm{C}$ by the $50^{\text {th }}$ day. This temperature fluctuation resulted in low production of biogas during the first ten days of temperature drop, increased daily biogas production rate as temperature began to increase reaching a maximum of $5.1 \mathrm{ml} /$ day on the $25^{\text {th }}$ day at $29^{\circ} \mathrm{C}$, and then a decrease in biogas production as temperature dropped.

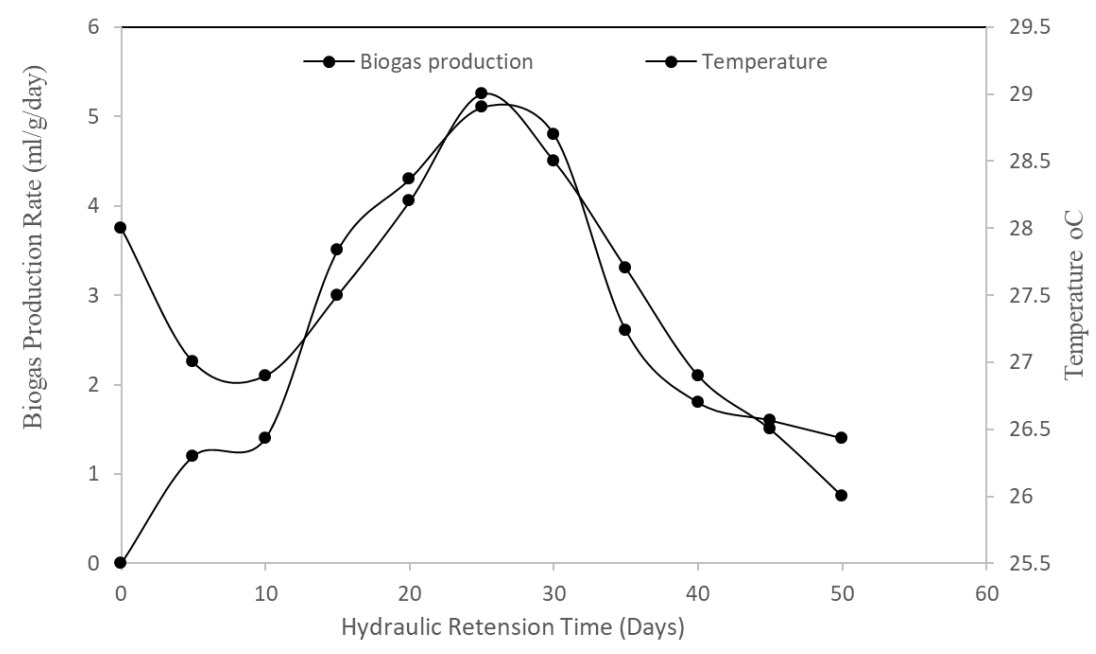

Figure 4. Changes in Temperatures and Biogas Production. 
These trends are in agreement with the proportional relation reported between temperature and gas production with biogas production increasing as temperature of fermentation slurry increases [25]. The temperature range of this experiment confirms that biogas production occurs at the mesophilic temperature.

\subsection{Kinetic Models of Biogas Production}

The five kinetic models applied in this study were fitted to the experimental data using the Matlab curve fitting tool box at a coefficient confidence bound of $95 \%$ to obtain the constants in each of the kinetic models. The curve fit of the experimental data for the five models with their constants and correlation coefficient $\left(\mathrm{R}^{2}\right)$ evaluated are shown thus.

\subsubsection{Linear Model}

The rate of production of biogas in the ascending and descending limb fitted with the linear model are shown in Figures 5 and 6 respectively.

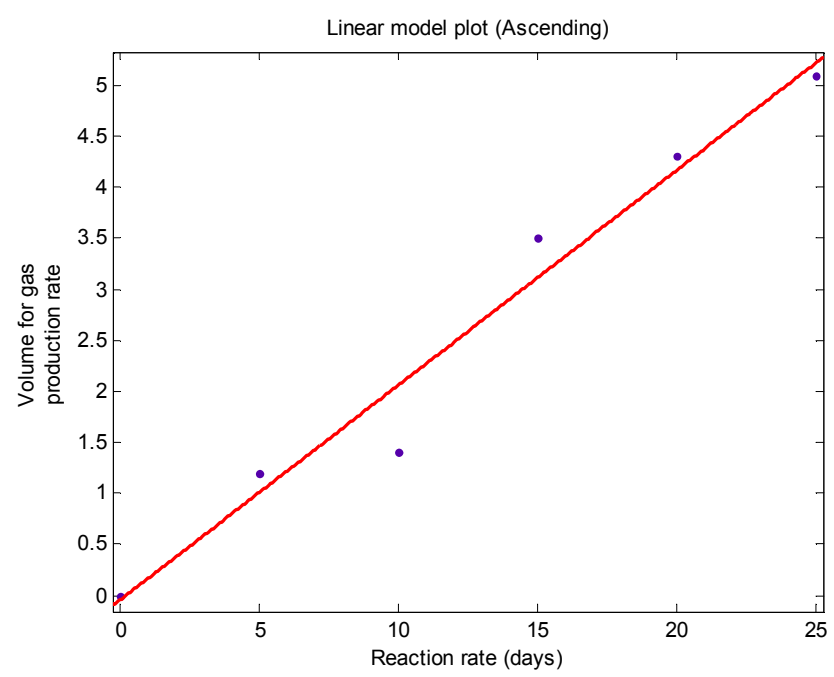

Figure 5. Linear Model for Ascending Climb.

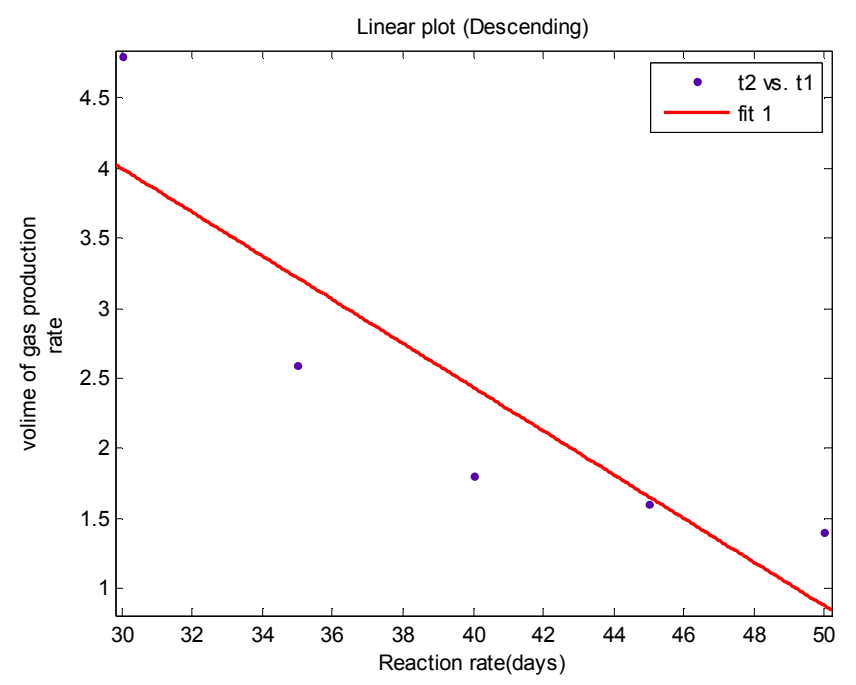

Figure 6. Linear Model for Descending Climb.
Thus, the biogas production rate increased linearly with time (ascending climb) reaching a maximum point after which production rate began to decrease linearly with time (descending climb). The correlation coefficient $\left(\mathrm{R}^{2}\right)$ of the linear model to the biogas production rate are 0.9673 and 0.7808 for the ascending and descending climb respectively.

\subsubsection{Exponential Model}

The ascending and descending limb fitted with the exponential model for biogas production are shown in Figures 7 and 8 respectively.

It can be seen from the Figures that biogas production rate increased exponentially with time (ascending climb) reaching a maximum point after which production rate began to decrease exponentially with time (descending climb). The correlation coefficient $\left(\mathrm{R}^{2}\right)$ of the exponential model for the biogas production rate yielded 0.9674 and 0.779 for the ascending and descending climb respectively.

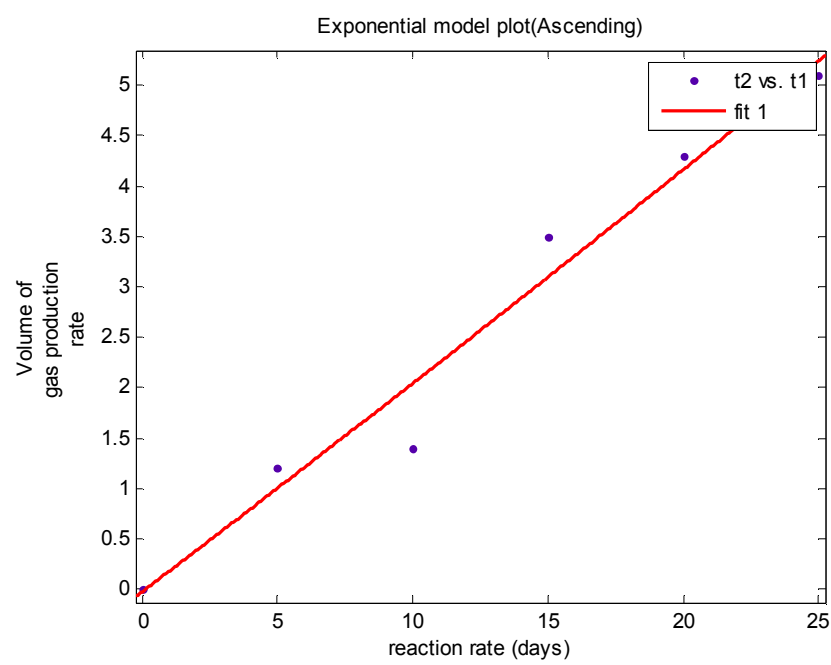

Figure 7. Exponential Model for Ascending Climb.

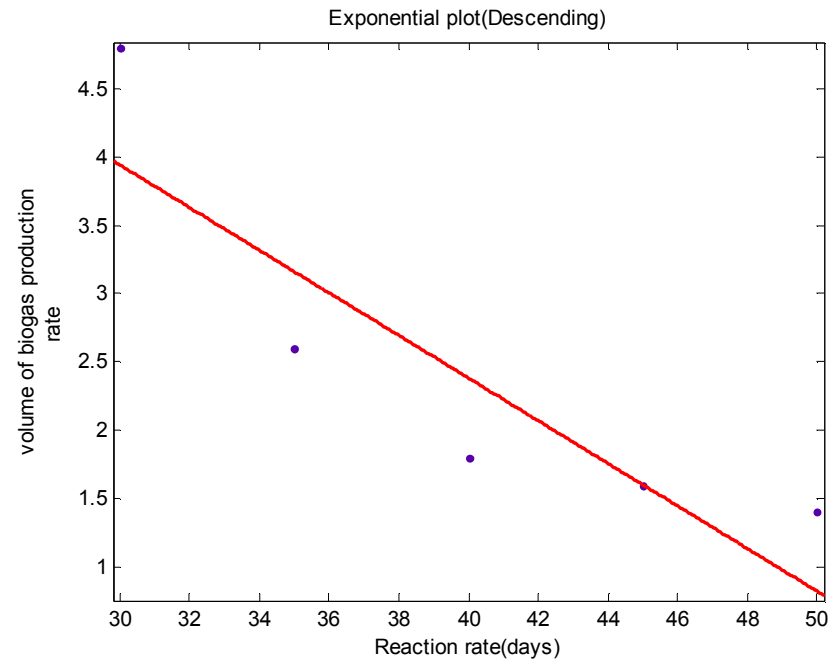

Figure 8. Exponential Model for Descending Climb. 


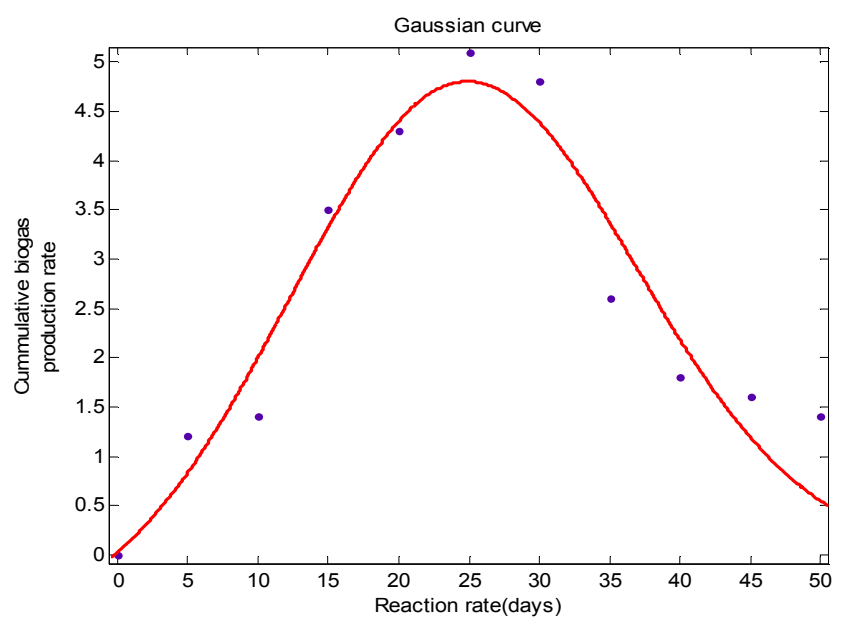

Figure 9. Gaussian Model of the Daily Biogas Production.

\subsubsection{Gaussian Model}

The daily biogas production data fitted with the Gaussian model yielded a curve that attains maximum biogas production after which a steady decrease in the production as shown in Figure 9. The correlation coefficient $\left(\mathrm{R}^{2}\right)$ of the Gaussian model for the biogas production rate is 0.9132 .

\subsubsection{Logistic Growth Model}

The Logistic Growth model fit of the cumulative daily biogas production data increases steadily from zeroth to $50^{\text {th }}$ day, with the correlation coefficient $\left(\mathrm{R}^{2}\right)$ for the biogas production rate as 0.9979 .

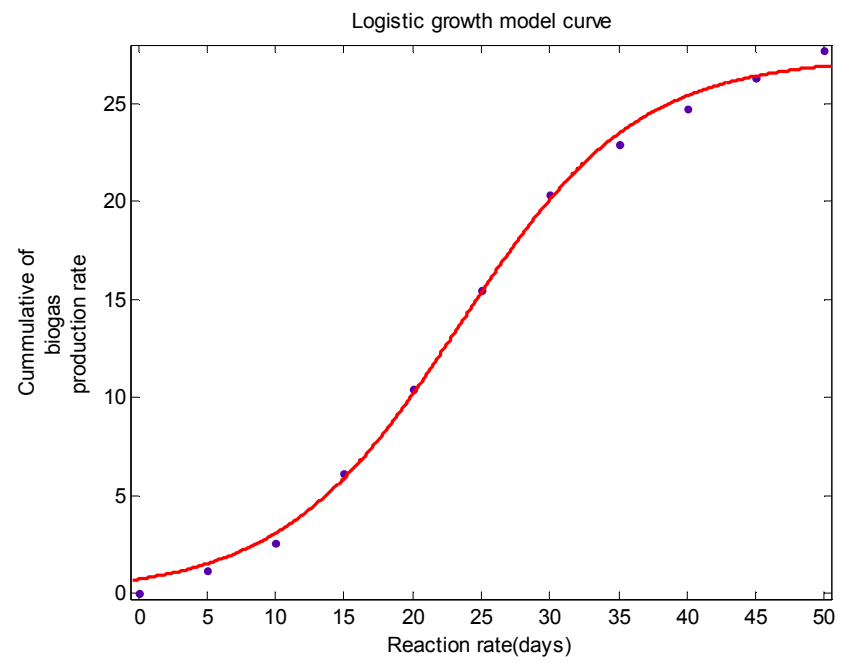

\subsubsection{Gompertz Model}

The Gompertz model fit of the cumulative daily biogas production data also shown a steady increase along the experimental days in similarity to the Logistic growth model and a correlation coefficient $\left(\mathrm{R}^{2}\right)$ of 0.999 for the biogas production rate.

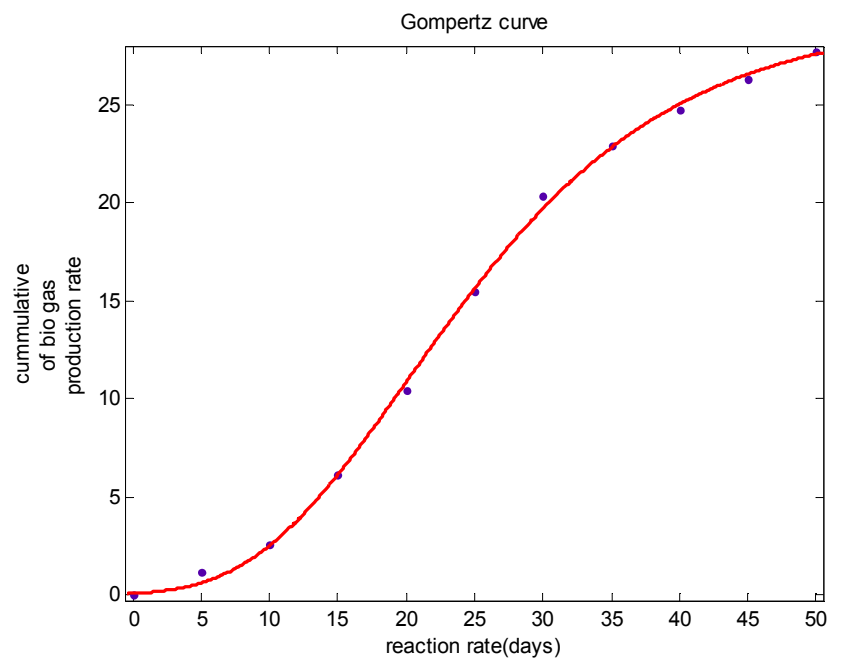

Figure 11. Gompertz Model of the Cumulative Biogas Production.

Furthermore, the daily production data showed that the coefficient of correlation $\left(\mathrm{R}^{2}\right)$ for Linear model (ascending and descending climb) are 0.9673 and 0.7808 , Exponential model (ascending and descending climb) are 0.9742 and 0.779 and Gaussian model yielded 0.9132 respectively. Also, the cumulative data showed that the coefficients of correlation for Logistic Growth and Modified Gompertz models are 0.9979 and 0.999 respectively. Thus, these models (Logistic Growth and Modified Gompertz) are useful for the simulation of biogas production from cow dung.

The modified Gompertz model also predicted the biogas production potential of $28.13 \mathrm{ml} / \mathrm{gm}$, minimum time required for biogas production (lag phase) of 2.96 days and a maximum biogas production rate of $5.37 \mathrm{ml} / \mathrm{gm} /$ day. The values of these parameters are in tandem with the evaluated experimental data of biogas production potential of 27.7 $\mathrm{ml} / \mathrm{gm}$, minimum time required to produce biogas (lag phase) of 3 days and a maximum biogas production rate of 5.1 $\mathrm{ml} / \mathrm{gm} /$ day.

Figure 10. Logistic Growth Model of the Cumulative Biogas Production.

Table 3. Kinetic Parameter of the Various Models.

\begin{tabular}{lll}
\hline Equations & Value of Parameters & R-Squared Values \\
\hline$y=a+b T$ & $\mathrm{a}=2.583$ \\
(Linear Ascending) & $\mathrm{b}=1.972$ \\
$y=a+b T$ & $\mathrm{a}=2.44$ \\
(Linear Descending) & $\mathrm{b}=-1.233$ \\
$y=a+b \exp (c T)$ & $\mathrm{a}=-82.55$ \\
(Exponential Ascending) & $\mathrm{b}=85.12$ \\
& $\mathrm{c}=0.02317$ \\
$y=a+b \exp (c T)$ & $\mathrm{a}=4551$ & 0.7808 \\
\end{tabular}




\begin{tabular}{lll}
\hline Equations & Value of Parameters & R-Squared Values \\
\hline (Exponential Descending) & $\mathrm{c}=0.00002711$ & $\mathrm{a} 1=-0.6996$ \\
$Y=a 1 \exp \left[\frac{T-T_{01}}{b 1}\right]^{2}+a 2 \exp \left[\frac{T-T_{02}}{b 2}\right]^{2}$ (Gaussian model) & $\mathrm{T}_{01}=-2.055$ & 0.9132 \\
& $\mathrm{~b}_{1}=1.601$ \\
$Y=\frac{a}{1-\exp (-k T)}($ Logistic Growth model) & $\mathrm{a}_{2}=4.942$ \\
& $\mathrm{~T}_{02}=-0.0276$ & 0.9979 \\
& $\mathrm{~b}=1.038$ \\
$Y=A \exp \left[-\exp \left[\frac{u e}{A}(\lambda-T)+1\right]\right]$ (Gompertz model) & $\mathrm{a}=27.3$ \\
& $\mathrm{~b}=-0.7789$ & $\mathrm{k}=2.564$ \\
& $\mathrm{~A}=28.13$ & \\
& $\lambda=2.96$ \\
& $\mathrm{U}=5.37$ & 0.999 \\
\hline
\end{tabular}

\subsection{Bioreactor Model}

The performance of the bioreactor (Cumulative Biogas production rate) as predicted by the model (from the solution of the component balance) showed a steady increase or change in cumulative biogas production rate as the experiment progressed as depicted in Figure 12.

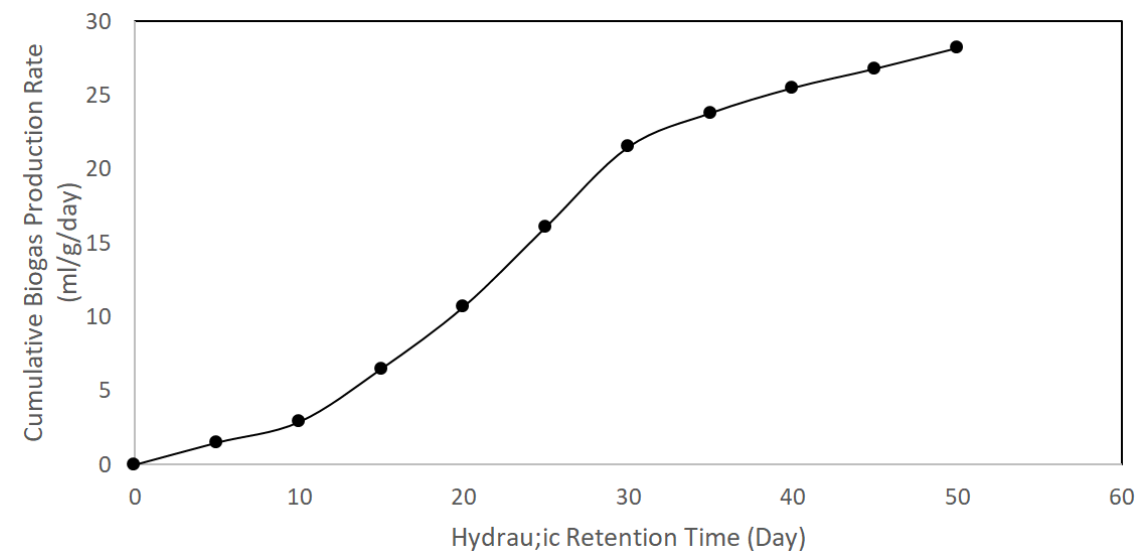

Figure 12. Model Prediction of Cumulative Biogas Production rate.

Also, the model prediction and experimental results of the cumulative biogas production rate in the bioreactor gave a good best fits as shown in Figures 13.

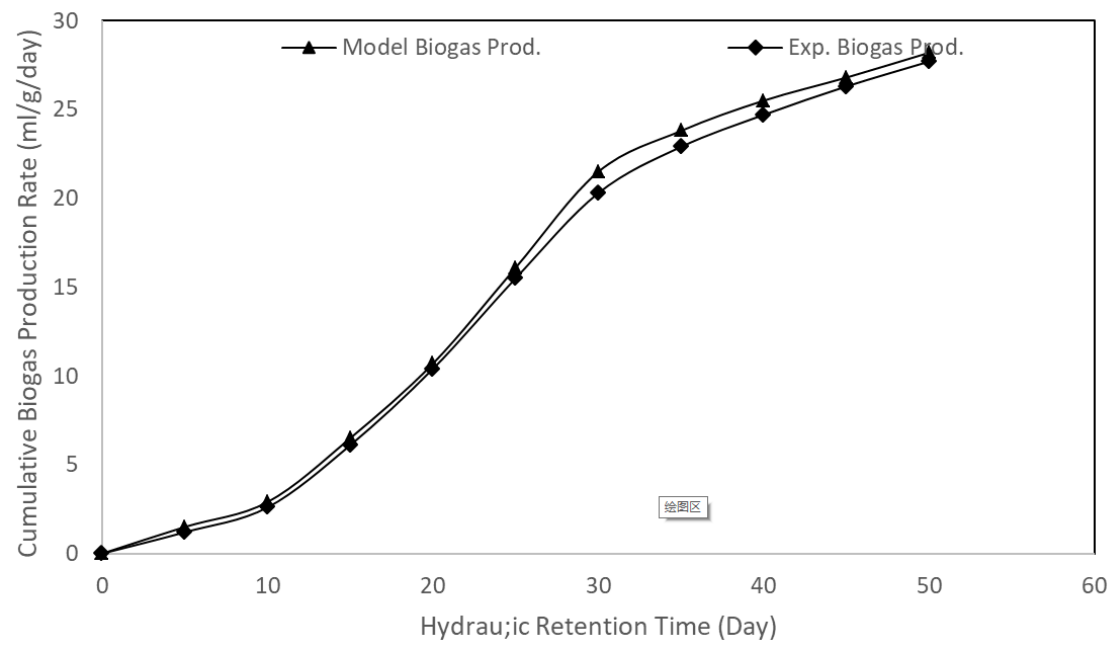

Figure 13. Model Prediction and Experimental data of Cumulative Biogas Production rate.

\subsection{Model Validation}

The degree of accuracy of the developed models was ascertained by comparing the cumulative biogas production rate predicted by the models with the experimental results. 
Table 4. Comparison of Experimental Result with Model Prediction.

\begin{tabular}{llll}
\hline PARAMETER & EXPERIMENTAL RESULT & MODEL PREDICTION & DEVIATION \% \\
\hline Cumulative Biogas Production (ml/g/day) & 27.7 & 28.13 & 1.53 \\
\hline
\end{tabular}

The deviation between the model predictions and the experimental results yielded a minimal value of $1.53 \%$ for the cumulative biogas production rate. Thus, this model can be used for simulation of the bioreactor.

\section{Conclusion}

A laboratory scale bioreactor was setup and used for the production of biogas from cow dung. The cow dung was characterized, temperature, $\mathrm{pH}$ and volume of biogas produced were measured at five (5) days' interval for the experiments' retention period of fifty days. The kinetics of the production process was tested by fitting the Linear, Exponential, Gaussian, Logistic growth and Gompertz model to the production data and a reactor model for the bio-digester was also developed with the logistic model kinetic constant of 2.564. The experimental results showed that temperature of the bio digester was between $28^{\circ} \mathrm{C}$ at the beginning, rose to a maximum of $29^{\circ} \mathrm{C}$ and decreased to $26^{\circ} \mathrm{C}$ at the end of fifty (50) days production (retention) period. Hence biogas production occurred within the mesophilic temperature of 27 to $30^{\circ} \mathrm{C}$. Also, the measured $\mathrm{pH}$ values were between 6.9 at the beginning, rose to 7 and decreased to 6.1 at fiftieth $\left(50^{\text {th }}\right)$ day and produced biogas volume of $27.7 \mathrm{ml} / \mathrm{g}$, maximum rate of biogas production of $5.1 \mathrm{ml} / \mathrm{g} /$ day and the minimum time needed for biogas production (the lag phase) was three days.

In addition, the kinetic evaluation of Linear, Exponential, Gaussian, Logistic Growth and Modified Gompertz models were deduced with the Logistic growth and Gompertz models fitted for biogas production kinetics. The reactor model developed solved with the Gompertz kinetic model predicted the biogas production process accurately with cumulative biogas production of $28.13 \mathrm{ml} / \mathrm{g}$ compared to the experimental cumulative production of $27.7 \mathrm{ml} / \mathrm{g}$ and a deviation of $1.53 \%$.

\section{Nomenclatures}

$\mathrm{y}$ : Biogas production rate $(\mathrm{ml} / \mathrm{gm} /$ day $)$

$\mathrm{T}$ : Time in day of digestion

a, b: Constants (ml/gm/day)

c: Constant (per day)

$\mathrm{T}_{\mathrm{o}}$ : Maximum biogas production rate.

Y: Cumulative biogas production $(\mathrm{ml} / \mathrm{gm})$

$\mathrm{K}$ : Kinetic rate constant (Per day)

T: RT (days)

A: Biogas production potential $(\mathrm{ml} / \mathrm{gm})$

$\mathrm{U}$ : Maximum biogas production rate $(\mathrm{ml} / \mathrm{gm} /$ day)

$\Lambda$ : Lag phase period or the minimum time required to produce biogas (day).

$\mathrm{T}$ : Time needed for digestion (days)
$R_{b g}:$ Cumulative Biogas Production Rate ( $\mathrm{ml} / \mathrm{g} /$ day)

$M_{s l}$ : Mass of Cow Dung Slurry $(\mathrm{g})$

$F_{i} ; F_{o}$ : Volumetric Flowrate of the Inlet and Outlet streams of the Bioreactor ( $\mathrm{ml} /$ day)

\section{References}

[1] Baki, A. S. (2004). Isolation and Identification of Microbe Associated with Biogas Production at Different Retention Time using Cow Dung, Master of Science Dissertation, Usman Dan Fodio University, Sokoto, Nigeria.

[2] Sunarso, O., Widiasa, S. J. \& Budiyono, I. N. (2012). The Effect of Feed to Inoculum Ratio on Biogas Production Rate from Cattle Manure Using Rumen Fluid Inoculum. Journal of Waste Resources.

[3] Meena, K. \& Vijay, V. K. (2010). Biogas for Overcoming Energy Scarcity and Climate Change in India, Proceedings of the First International Conference on New Frontiers in Biofuels, DTU Jan. 18-19, 2010, New Delhi, India.

[4] Yusuf, M. O. L., Debora, A. \& Ogheneruona, D. E. (2011). Ambient Temperature Kinetic Assessment of Biogas Production from Co-Digestion of Horse and Cow Dung. Research in Agricultural Engineering, 57, 97-104.

[5] Shete, B. S. \& Shinkar, N. P. (2017). Anaerobic Digestion of Diary Industry Waste Water-Biogas Evolution-A Review. International Journal of Applied Environmental Sciences, 12, $6,1117-1130$.

[6] Rabah, A. B., Baki, A. S., Hassan, L. G., Musa, M. \& Ibrahim, A. D. (2010). Production of Biogas Using Abattoir Waste at Different Retention Time. Science World Journal, 5, 4, 23-26.

[7] Alfa, M. I., Adie, D. B., Iorhemen, O. T., Okafor, C. C., Ajayi, S. A., Dahunsi, S. O. \& Akali, D. M. (2013). Assessment of Mesophilic Co-Digestion of Cow Dung with Lemon Grass for Biogas Production. Nigerian Journal of Technology, 32, 3, 478-484.

[8] Rabiu, A., Yaakub, H., Liang, J. B. \& Samsudin, A. A. (2014). Increasing Biogas Production of Rumen Fluid using Cattle Manure Collected at Different Time as a Substrate. IOSR Journal of Agriculture and Veterinary Science (IOSR-JAVS), $7,4,44-47$.

[9] Vikrant, D. \& Shekhar, P. (2013). Generation of Biogas from Kitchen Waste -Experimental Analysis, International Journal of Engineering Science Invention, 2, 10, 15-19.

[10] Pratima, K. C. \& Bhakta, B. A. (2015). Production of Biogas from Slaughterhouse Waste in Lalitpur Sub-Metropolitan City, Proceedings of IOE Graduate Conference, 143-149.

[11] Clescerl, L. S., Greenberg, A. E. \& Eaton, A. D. (1985). Stand $\neg$ ard Method for the Examination of Water and Wastewater. 16th Ed. Washington D.C., APHA.

[12] American Public Health Association (1998). Standard Method for the Examination of Water and Waste Water 15th Ed., APHA, Washington DC, USA. 
[13] Ahmad, J. \& Ansari, T. A. (2012). Biogas from Slaughter House Water: Towards an Energy Self-Sufficient Industry with Economical Analysis in India. Microbial \& Biochemical Technology Journal, available at: http://dx.doi.org/10.4172/1984-5948.S12-001

[14] Kumar, S., Mondal, A. N., Gaikward, S. A., Derotta, S. \& Singh, R. N. (2004). Qualitative Assessment of Methane Emission Inventory from Muicipal Solid Waste Disposal Sites: A Case Study. Amos Ennion. 38, 4921 - 4929.

[15] Lo., H. M., Kurniawan, T. A., Sillanpaa, M. E. T., Pai, T. Y. \& Chiang, C. F. (2010). Modelling Biogas Production from Organic Function of MSW Co-Digested with MSWI Ashes in Anaerobc Bioreactors. Bio Resources Technology, 101, 63296335 .

[16] De Gioannis, G., Mantoni, A., Cappai, G. \& Milia, S. (2009). Landfull Gas Generation after Mechanical Biological Treatment of Manicipal Solid Waste: Estimation of Gas Generation Rate Constants. Waste Manage, 29, 1026-1034.

[17] Hills, D. J. \& Roberts, D. W. (1981) Anaerobic Digestion of Dairy Manure and Field Crop Residues. Agricultural Wastes, 3, 179-189.

[18] Budiyono, I. N., Widiasa, S. J. \& Sunarso, O. (2010). The Kinetic of Biogas Production Rate from Cattle Manure in Batch Mode. International Journal of Chemical and Biological Engineering, 10, 1, 68-75.

[19] Mahanta, P., Dewan, A., Saha, U. K. \& Kalita, P. (2004).
Effect of temperature and total solid concentration on the gas production rate of biogas digester. Journal of Energy in Southern Africa, 15, 4, 112-117.

[20] Lazcano, C., Gomez, M. B. \& Dominguez, J. (2008). Comparison of the Effectiveness of Composting and VermiComposting for the Biological Stabilization of Cattle Manure. Chemosphere., T72: 1013-1019.

[21] Kiyasudeen, K. S., Ibrahim, M. H. \& Ismail, S. A. (2015). Characterization of Fresh Cattle Wastes Using Proximate, Microbial and Spectroscopic Principles. American-Eurasian J. Agric. \& Environ. Sci., 15, 8, 1700-1709.

[22] Shehu, B., Abubakar, U. I. \& Ismail, N. (2012). Anaerobic Digestion of Cow Dung for Biogas Production, ARPN Journal of Engineering and Applied Sciences, 7, 2, $169-172$.

[23] Hashimoto, G, \& Varriel, H. (1978). Factors Affecting Methane Yield and Production Rate. American Society of Agricultural Engineers (ASAE). St Joseph, ML: 49085. http: //www.usaid.gov/stores/Srilanka-biogas.Htm, 68.

[24] Angelika, I. \& Ellegaard, L. (2003). Co-Digestion of Manure and Organic Wastes in Centralized Biogas Plant: Status and Future Trend. Environmental and Resources, Technical University of Denmark.

[25] Latinwo, G. K. \& Agarry, S. E. (2015). Modelling the Kinetics of Biogas Generation from Mesophilic Anaerobic CoDigestion of Sewage Sludge with Municipal Organic Waste. Chemical and Process Engineering Research, 13, 43 - 53. 